\title{
Biology and thermal requirements of Telenomus remus reared on fall armyworm Spodoptera frugiperda eggs
}

\author{
Características biológicas e exigências térmicas de Telenomus remus em ovos \\ de Spodoptera frugiperda
}

\author{
Regiane Cristina Oliveira de Freitas Bueno ${ }^{\mathrm{I}}$ Tatiana Rodrigues Carneiro ${ }^{\mathrm{II}}$ \\ Dirceu Pratissoli"II Adeney de Freitas Bueno ${ }^{\text {IV }}$ Odair Aparecido Fernandes ${ }^{I I}$
}

\begin{abstract}
This research aimed at studing Telenomus remus Nixon biology reared on Spodoptera frugiperda (J.E. Smith) eggs at different temperatures. Based on the development of the cycle (egg-adult), the thermal requirements and the number of parasitoid generations at constant temperatures were determined. Initially, 24-hour-old $\boldsymbol{S}$. frugiperda eggs were submitted to parasitism by $\boldsymbol{T}$. remus during $5 \mathrm{~h}$, being then transferred to acclimatized chambers regulated at 15, 20, 25, 28,31 , and $35^{\circ} \mathrm{C}$. The cycle (egg to adult) was influenced by temperature varying from $8.3 \pm 0.01$ to $47.2 \pm 0.01$ for females and $8.1 \pm 0.01$ to $46.8 \pm 0.01$ days for males at 31 and $15^{\circ} \mathrm{C}$, respectively. The emergency (\%) was also influenced by temperature. A reduction in emergency was observed at $15^{\circ} \mathrm{C}$ and no emergency at $35^{\circ} \mathrm{C}$. T. remus sex ratio was not influenced by temperature. Sexual rate was not changed by temperature. Regarding to thermal requirements, thermal constant $(K)$ and inferior thermal threshold (Tb) were higher for T. remus females (158.88 degree-days and $12.5^{\circ} \mathrm{C}$ ) when compared to males (154.12 degree-days and $12.6^{\circ} \mathrm{C}$ ). The estimated number of $\mathbf{T}$. remus generation per year for males and females at laboratory conditions was 5.6 and 5.6, 16.9 and 17.3, 28.3 and 29.0, 35.1 and 36.0, 39.6 and 40.7 at 15, 20, 25, 28, and 31oC, respectively.
\end{abstract}

Key words: integrated pest management, biological control, eggs parasitoid, degree-days.

\section{RESUMO}

Este trabalho teve como objetivo estudar a biologia de Telenomus remus Nixon criado em ovos de Spodoptera frugiperda (J.E. Smith) em diferentes temperaturas. Com base no desenvolvimento do ciclo (ovo-adulto), foram determinados as exigências térmicas e o número de gerações dos parasitóides em temperaturas constantes. Inicialmente, ovos de $\mathrm{S}$. frugiperda, com 24 horas de idade, foram submetidos ao parasitismo por T. remus, durante cinco horas, sendo então transferidos para câmaras climatizadas reguladas para as temperaturas de 15, 20, 25, 28, 31 e $35^{\circ} \mathrm{C}$. A duração do ciclo (ovo-adulto) foi influenciada pela temperatura variando de

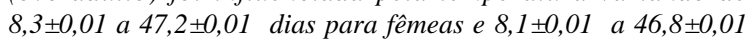
dias para machos de T. remus nas temperaturas de 31 e $15^{\circ} \mathrm{C}$, respectivamente. A porcentagem de emergência (viabilidade) de $\boldsymbol{T}$. remus em ovos de $\boldsymbol{S}$. frugiperda também foi influenciada pela variação da temperatura, apresentando redução significativa apenas nas temperaturas extremas. Foi observada redução na viabilidade a $15^{\circ} \mathrm{C}$ e não houve desenvolvimento biológico do parasitóide a $35^{\circ} \mathrm{C}$. A razão sexual de $\mathrm{T}$. remus não sofreu influência da temperatura. Em relação às exigências térmicas, a constante térmica (K) e temperatura base (Tb) foram maiores para as fêmeas de $\mathbf{T}$. remus $(158,88$ graus dias e $12,52^{\circ} \mathrm{C}$ ) quando comparadas aos machos (154,12 graus dias e $\left.12,59^{\circ} \mathrm{C}\right)$. A estimativa do número de gerações anuais para T. remus para machos e fêmeas em condições de laboratório foi respectivamente 5,6 e 5,6; 16,9 e 17,3; 28,3 e 29,0; 35,1 e 36,0; 39,6 e 40,7 nas temperaturas de 15, 20, 25, 28 e $31^{\circ} \mathrm{C}$

Palavras-chave: manejo integrado de pragas, controle biológico, parasitóides de ovos, graus-dia.

\section{INTRODUCTION}

Fall armyworm, Spodoptera frugiperda (J.E. Smith) (Lepidoptera: Noctuidae), damages several

\footnotetext{
'Departamento de Entomologia, Fitopatologia e Zoologia Agrícola, Escola Superior de Agricultura “Luiz de Queiroz”, Universidade de São Paulo (ESALQ/USP), 13418-900, Piracicaba, SP, Brasil. Endereço para correspondência: Condomínio Monte Verde Casa 156, Rua Dona Firmina, s/n, 74681-450, Bairro Sítio Recreio dos Ipês, Goiânia, GO, Brasil. E-mail: rcdolive@esalq.usp.br. IIDepartamento de Fitossanidade, Universidade Estadual Paulista “Julio de Mesquita Filho”, Universidade Estadual de São Paulo (UNESP), Jaboticabal, SP, Brasil.

IIIDepartamento de Fitotecnia, Centro de Ciências Agrárias (CCA), Universidade Federal do Espírito Santo (UFES), Alegre, ES, Brasil.

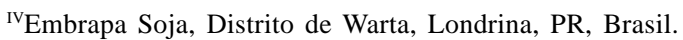


crops and is considered a key pest for corn. This species is responsible for corn harvest reduction in commercial crops around the world (FIGUEIREDO et al., 2002).

Insecticide use has been the tool frequently chosen by growers to control fall armyworm outbreaks and most sprayings are due to this pest. Close to US\$ 60 million is annually spent by corn growers in Brazil with insecticides bills due to $\boldsymbol{S}$. frugiperda outbreaks. This excessive insecticide use has brought several unwanted side effects such as insecticide resistance and natural biological control decrease, what helps to increase corn production costs (DIEZ-RODRIGUEZ \& OMOTO, 2001; CRUZ, 1995).

An important measure to reduce this problem is by increasing other control tool besides pesticides. Biological control has been pointed out by researchers among the alternatives as economically and ecologically possible to be used, helping to decrease the damage caused by agriculture to the environment (CRUZ, 1995; PRATISSOLI \& PARRA, 2000).

Egg parasitoids have shown the best performance among $\boldsymbol{S}$. frugiperda biological control agents, being Telenomus remus Nixon (Hymenoptera: Scelionade) an important control agent due to its capacity to parasite the whole egg mass (FIGUEIREDO et al., 2002). T. remus has been largely used in Integrated Pest Management programs in Venezuela in corn, reaching control levels up to 90\% (GONZÁLEZ \& ZOCCO, 1996; FERRER, 2001).

Several researches have been carried out around the world aiming to evaluate $\mathbf{T}$. remus efficacy on S. frugiperda eggs (JOSHI et al., 1976; GUPTA \& PAWAR, 1985). However, few works have been addressed it in Brazil (FIGUEIREDO et al., 1999 and 2002). An important aspect in biological control efficacy is temperature requirement. Through mathematical models it is possible to forecast pest occurrence as well as their biological control agent occurrence (HIGLEY et al., 1986).

Furthermore, knowing the parasitoid temperature requirements it is possible to control laboratorial livestock of this insect aiming later release. Temperature requirements might be shown through the thermal constant $(\mathrm{K})$ expressed in degree-days, supporting that insect life cycle duration is defined by the temperature sum, calculated from a minimum temperature threshold (PARRA, 1997).

The great importance of knowing temperature requirements was pointed out by PRATISSOLI \& PARRA (2000), when they said Trichogramma pretiosum temperature requirements knowledge allows to know optimum temperature to insect development, better synchronism of parasitoid livestock, helping to increase Integrated Pest Management (IPM) performance when this parasitoid is used. Therefore, this research aimed to better understand $\mathbf{T}$. remus temperature requirements to enhance its use in $\boldsymbol{S}$. frugiperda control inside an IPM program.

\section{MATERIALS AND METHODS}

The experiment was carried out at the 'Universidade Estadual Paulista, UNESP', Campus of Jaboticabal, SP, Brazil. S. frugiperda livestock adults were kept in cages where the eggs were collected. Adult feeding was honeyed water. Each egg mass removed was placed in a plastic cup with 5 grams of artificial diet and kept in a room with controlled temperature and relative humidity $\left(25 \pm 1^{\circ} \mathrm{C}, \mathrm{RH} 70 \pm 10 \%\right.$, and $12 \mathrm{~L}$ : $\left.12 \mathrm{D}\right)$. $S$. frugiperda larvae were grown individualized to avoid cannibalism until pupation. Pupae were then separated according to sex and then new cages were set up with seven couples each (OLIVEIRA et al., 2006). The artificial diet used was adapted from KASTEN Jr. et al. (1978).

T. remus livestock was set up with insects received from 'EMBRAPA Milho e Sorgo' livestock. $\boldsymbol{S}$. frugiperda egg masses removed from the livestock, without any special treatment, were glued on a cardboard square $(2.5 \mathrm{~cm}$ per $5 \mathrm{~cm})$. Three of these squares having the eggs were then placed into a glass tube ( $8 \mathrm{~cm}$ high and $2 \mathrm{~cm}$ of diameter) with eggs previously parasited by $\mathbf{T}$. remus. Inside these tubes small honey drops were placed to feed the adults when emerged. These tubes were properly tapped with polyvinyl chloride (PVC) transparent film and then $\boldsymbol{T}$. remus parasitism was allowed for 24 hours. The insects were kept under controlled conditions $\left(25 \pm 1^{\circ} \mathrm{C}\right.$, RH $70 \pm 10 \%$, and 12L: 12D) and new $\boldsymbol{S}$. frugiperda eggs were offered to $\mathbf{T}$. remus on a daily basis.

Trial evaluating both the behavior aspects and temperature effects on $\mathbf{T}$. remus development growth on $\boldsymbol{S}$. frugiperda eggs masses was set up with 100 eggs per replication laid into a 24-hour interval. These eggs were glued on a cardboard $(2.5 \mathrm{~cm}$ per $5 \mathrm{~cm})$. This cardboard having the eggs was individually placed into a glass tube ( $8 \mathrm{~cm}$ high and $2 \mathrm{~cm}$ of diameter). Ten T. remus female were placed into each tube and a total of 12 tubes were set up for each treatment (different temperature). Parasitism was allowed by 5 hours under controlled conditions $\left(25 \pm 1^{\circ} \mathrm{C}, \mathrm{RH} 70 \pm 10 \%\right.$, and $12 \mathrm{~L}$ : 12D).

During the 5-hour period, the female behavior was visually observed and all the 
characteristics registered. By the end of the period, females were removed using a stereoscopic microscopic. Each group of 12 tubes was then transferred to the different temperatures $(15,20,25,28$, 31 and $35 \pm 1{ }^{\circ} \mathrm{C}, \mathrm{RH} 70 \pm 10 \%$, and $12 \mathrm{~L}$ : $\left.12 \mathrm{D}\right)$. During the whole period trial was been carried out, evaluations were done on a daily basis using a stereoscopic microscopic. The evaluated parameters were: development time from egg to adult differencing male and female; percentage of emergency (viability); sex rate; number of $\boldsymbol{T}$. remus emerged per $\boldsymbol{S}$. frugiperda egg. The number of $\boldsymbol{S}$. frugiperda eggs having the hatching roles caused by $\mathbf{T}$. remus emergency was the parameter counted to precisely estimate the number of parasitoid emerged at that day per egg.

The experiment was set up in a totally randomized design with 6 treatments and 12 replications. Data were analyzed using variance analysis (ANOVA) and means were separated using Tukey's test $(\mathrm{P} \leq 0.05)$. Inferior thermal threshold (Tb) and thermal constant (K) values were calculated by the hyperbole methodology proposed by HADDAD et al. (1995), using the computer program MOBAE and having as reference the development time of $\boldsymbol{T}$. remus (egg to adult) in the tested temperatures.

The number of $\boldsymbol{T}$. remus generations per year in laboratory conditions was estimated using the equation $\mathrm{NG}=\{\mathrm{T}(\mathrm{Tm}-\mathrm{Tb}) / \mathrm{K}\}$ where: $\mathrm{K}=$ thermal constant; $\mathrm{Tm}=$ average temperature; $\mathrm{Tb}=$ inferior thermal threshold and $\mathrm{T}=$ time in days.

\section{RESULTS AND DISCUSSION}

Behavior aspects:

The parasitoid laying process begins after an examination of the $\boldsymbol{S}$. frugiperda eggs done by $\boldsymbol{T}$. remus females. T. remus females forage on the top of the $\boldsymbol{S}$. frugiperda eggs and use the antenna to precisely exam each egg. This process is generally used by parasitoids to exam egg shape, texture and chemical substances in order to carefully identify host suitability. This offers the capacity of choosing the best egg species to develop new progenies (VINSON, 1997).

S. frugiperda egg mass was totally used by T. remus since it was verified parasitism in the whole egg mass. This gives high efficacy to T. remus biological control programs since it does not allow the emergence of any larvae from the $\boldsymbol{S}$. frugiperda egg mass. Comparing to other eggs parasitoids, this characteristic makes $T$. remus a more aggressive parasitoid on a Spodoptera spp. egg mass than Trichogramma spp., for example. It happens because when the female Spodoptera spp. lays an egg mass, she covers it with scales from her body; these scales and the multiple layers of eggs make a formidable barrier to Trichogramma spp. females (which are smaller and more delicate than $\mathbf{T}$. remus), thus they can parasitize only some (usually only those in the top layer) of the eggs in the egg mass (CAVE, 2000).

At the end of the parasitoid development, the adult parasitoid hatches through a small role done on the $\boldsymbol{S}$. frugiperda egg. In general, female emergency happens some hours later than male emergency. Males newly emerged stay still next to the eggs mass until the emergency of the females. The males help the female emergency and immediately after that the breeding happens. After mating females start searching for host eggs. According to CAVE (2000) they are attracted by chemical substances such as (Z)-9-tetradeceno-1-ol acetate and (Z)-9-dodeceno-1-ol acetate which are present in S. frugiperda eggs.

\section{Biological characteristics}

T. remus development time from egg to adult was inversely related to temperature increase, having statistical difference in all tested temperatures (Table 1). However, it was observed the decrease in time from egg to adult was lower from 25 to $31^{\circ} \mathrm{C}$ than 15 to $20^{\circ} \mathrm{C}$ and at $3^{\circ} \mathrm{C}$ there was no T. remus development (Table 1). Dark eggs were observed between 3 to 4 days after parasitism had occurred at $25^{\circ} \mathrm{C}$ and above. At temperatures from 15 to $20^{\circ} \mathrm{C}$ dark eggs were just observed 12 days after parasitism. Development time from egg to adult was 8.3 and 8.1 days at $31^{\circ} \mathrm{C}$ and 47.2 and 46.8 days at $15^{\circ} \mathrm{C}$ for males and females, respectively (Table 1 ). Therefore, the increase in temperature from 15 to $31^{\circ} \mathrm{C}$ caused a reduction in the parasitoid egg-to-adult cycle of 38.9 and 38.7 days for males and females, respectively.

T. remus development time required from egg to adult is reduced by an increase in temperature due to an increase in metabolic activity of the parasitoids (HERNÁNDEZ \& DIÁZ, 1996). This reduction occurs until a superior limit of temperature that allows the insect survival. Our results on development time (egg to adult) are similar to the ones reported by GERLING (1972) who studied this biological parameter just at temperatures of 22 and $25^{\circ} \mathrm{C}$. Other species of Telenomus might require different time to develop from egg to adult (GERLING, 1972; HERNÁNDEZ \& DIÁZ, 1996). Therefore, this biological parameter relies on temperature as well as insect race adaptation. It was verified for Trichogramma pretiosum (PRATISSOLI \& PARRA, 2000).

T. remus emergency (egg viability) on $\boldsymbol{S}$. frugiperda eggs was also affected by temperature 
Table 1 - Biological parameters of $\boldsymbol{T}$. remus raised on $\boldsymbol{S}$. frugiperda eggs on different temperatures (RH $70 \pm 10 \%$ and $12 \mathrm{~L}$ : 12D).

\begin{tabular}{|c|c|c|c|c|c|}
\hline \multirow{2}{*}{ Temperature ${ }^{\circ} \mathrm{C}$} & \multicolumn{2}{|c|}{ Time required from egg to adult $( \pm$ SEM) } & \multirow{2}{*}{ Viability (\%) } & \multirow{2}{*}{ Sexual rate } & \multirow{2}{*}{$\begin{array}{c}\text { Number of parasitoid } \\
\text { emerged/egg }\end{array}$} \\
\hline & Female & Male & & & \\
\hline 15 & $47.2 \pm 0.01 \mathrm{a}$ & $46.8+0.01 \mathrm{a}$ & $13.0+0.001 \mathrm{a}$ & $0.45+0.06 \mathrm{a}$ & 1 \\
\hline 20 & $24.2+0.01 \mathrm{~b}$ & $23.8+0.01 b$ & $99.7+0.001 b$ & $0.54+0.03 \mathrm{ab}$ & 1 \\
\hline 25 & $13.5 \pm 0.01 \mathrm{c}$ & $13.2 \pm 0.01 \mathrm{c}$ & $99.4+0.001 \mathrm{~b}$ & $0.59 \pm 0.04 \mathrm{~b}$ & 1 \\
\hline 28 & $10.2 \pm 0.01 \mathrm{~d}$ & $9.9 \pm 0.01 \mathrm{~d}$ & $99.7 \pm 0.001 \mathrm{~b}$ & $0.51+0.01 \mathrm{ab}$ & 1 \\
\hline 31 & $8.3 \pm 0.01 \mathrm{e}$ & $8.1 \pm 0.01 \mathrm{e}$ & $99.7 \pm 0.001 \mathrm{~b}$ & $0.51 \pm 0.02 \mathrm{ab}$ & 1 \\
\hline 35 & $*$ & $*$ & $0.0 \pm 0.000 \mathrm{c}$ & $*$ & 1 \\
\hline
\end{tabular}

Means \pm Standard Error Medium (SEM) followed by the same letter are not statistically different $(\mathrm{P}>0.05)$.

* Inexistent parameter or non-calculable at tested temperature.

changes. These differences were statistically significant at 15 and $35^{\circ} \mathrm{C}$. Observed viability was $13 \%$ at $15^{\circ} \mathrm{C}$ and close to $100 \%$ at the other tested temperatures (20, 25, 28 and $31^{\circ} \mathrm{C}$ ). At $35^{\circ} \mathrm{C}$ no T. remus emergency occurred (Table 1). Similar results were shown by TORRES et al. (1997), when they raised Telenomus podisi on Podisus nigrispinus eggs. Our results show that temperature might be manipulated from 20 to $31^{\circ} \mathrm{C}$ at laboratory livestock aiming to accelerate or slow down the emergency of adults according to practical necessities. It is possible because the development is changed by temperatures inside this range without any damage to parasitoid viability.

T. remus emergency always occurred at the range of 1 parasitoid per host egg at all tested temperatures (Table 1), what means this biological parameter for $\mathbf{T}$. remus is not affected by temperature. The emergency of a single insect per host egg is probably due to mortality caused by a competition among the larva and/or food restrictions that allows only one parasitoid to fully develop (DASS \& PARSHAD, 1983). These results are different from the majority of egg parasitoid species raised at laboratory conditions. Normally, laboratory conditions favor super parasitism in egg parasitoid livestock (PARRA, 1996).

The relation between the number of $\boldsymbol{T}$. remus males and females (sexual rate) was statistically affected by the temperature from 15 to $25^{\circ} \mathrm{C}$. Sexual rate varied from 0.45 to 0.59 at 15 and $25^{\circ} \mathrm{C}$, respectively. Therefore, a greater number of males were obtained at $15^{\circ} \mathrm{C}$ when compared to $25^{\circ} \mathrm{C}$. It is negatively related to field efficacy since females are the parasitism responsible. However, this temperature did not differ from the others $\left(20,28\right.$, and $\left.31^{\circ} \mathrm{C}\right)$ (Table 1). Data from $35^{\circ} \mathrm{C}$ were not included at analysis as proposed by FINNEY (1989) because of there was not adult emergence in this temperature. T. remus males and females development occurred from 15 to $31^{\circ} \mathrm{C}$.
Our results show that temperature did not have a great impact on sexual rate. Other characteristic might have a greater impact on sexual rate such as female age. While a 2 to 3 day old female might have in 60 to $70 \%$ of her eggs emerging a female, this number might decrease to 22\% for older females (SCHWARTZ \& GERLING, 1974). Other factor interfering in sexual rate is the amount of available host eggs. T. remus females produce a greater number of males when there is a lack of host eggs (WELZEN \& WAAGE, 1987).

The inferior thermal threshold (Tb) was 12.5 and $12.6^{\circ} \mathrm{C}$, thermal constant (K) was 158.9 and 154.1 degree days for males and females, respectively (Figure $1 \mathrm{~A}$ and $1 \mathrm{~B})$. Therefore, a small change $\left(0.1^{\circ} \mathrm{C}\right)$ was observed. A change was also observed in the thermal constant (K) between $\boldsymbol{T}$. remus males and females. The velocity of development curve for both males and females (Figure 1A and 1B) had a coefficient of 98,43\% $\left(\mathrm{r}^{2}\right)$ being highly correlated temperature and development time.

The results show that females require a thermal increment to complete development (Figure 1A). Our results for thermal constant (158.88 and 154.12 for females and males respectively) were inferior to the results shown by TORRES et al. (1997) for T. podisi on P. nigrispus eggs at temperatures from 17 to $32^{\circ} \mathrm{C}$, which require a thermal increase of 205.3 and 107.6 for females and males, respectively. These variations among species might characterize temperatures effects on development estimated development (number of generations) is taken into consideration for a long period (TORRES et al., 1997).

The estimated number of $T$. remus generation per year for males and females at laboratory conditions was respectively 5.6 and 5.6, 16.9 and 17.3, 28.3 and 29.0, 35.1 and 36.0, 39.6 and 40.7 at temperatures of $15,20,25,28$, and $31^{\circ} \mathrm{C}$. This estimated number of generations at laboratory conditions was 


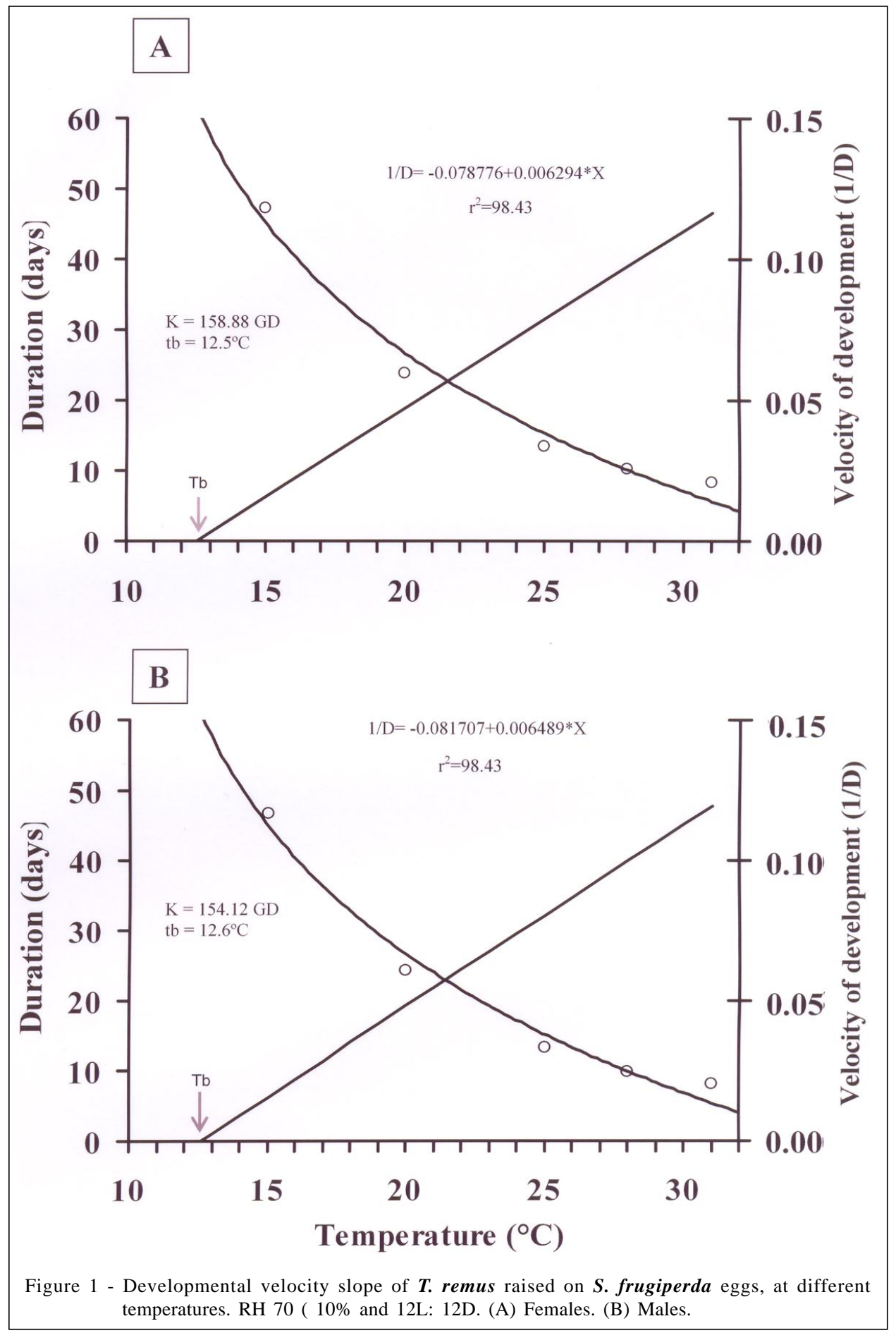

constant, being extremely important result for manipulating $\mathbf{T}$. remus livestock since it shows that under controlled conditions of laboratory it is possible to manipulate temperature aiming to increase or decrease parasitoid cycle in order to synchronize adult emergence according to field necessities. In the estimative of the number of generations at field conditions, the monthly average temperature must be used for each region, with the variation amplitude of the average that might influence $\boldsymbol{T}$. remus biological parameter resulting in development rates greater or slower than the laboratory ones (TORRES et al., 1997). 


\section{CONCLUSIONS}

The study of biological characteristics and temperature requirements of $\boldsymbol{T}$. remus raised on $\boldsymbol{S}$. frugiperda eggs brings important information for the development and implementation of biological control program involving this parasitoid. Analyzing the behavior aspects it is possible to conclude that $\boldsymbol{T}$. remus has similarities with other eggs parasitoids, carefully analyzing the host egg features before parasitizing. Also, our results suggest that $\mathbf{T}$. remus might be capable of developing all year long in field conditions. Furthermore, the number of generations of this parasitoid is a great indication of its great potential to control $\boldsymbol{S}$. frugiperda outbreaks.

\section{REFERENCES}

CAVE, R.D. Biology, ecology and use in pest management of Telenomus remus. Biocontrol News and Information, v.21, n.1, p. 21-26, 2000.

CRUZ, I. A lagarta-do-cartucho na cultura do milho. Sete Lagoas: EMBRAPA-CNPMS, 1995. 45p. (Circular Técnica 21).

DASS, R.; PARSHAD, B. Influence of age of Spodoptera litura (Fabricius) egg on parasitisation by Telenomus remus Nixon (Hymenoptera: Scelionidae). Journal of Entomological Research, v.8, p.89-92, 1983.

DIEZ-RODRIGUEZ, G.I.; OMOTO, C. Herança da resistência de Spodoptera frugiperda (J.E. Smith) (Lepidoptera: Noctuidae) à lambda-cialotrina. Neotropical Entomology, v.30, n.2, p.311-316, 2001.

FERRER, F. Biological control of agricultural insect pests in Venezuela; advances, achievements, and future perspectives. Biocontrol News and Information, v.22, n.3, p.67-74, 2001.

FIGUEIREDO, M.L.C. et al. Controle integrado de Spodoptera frugiperda (Smith \& Abbott) utilizando-se o parasitóide Telenomus remus Nixon. Pesquisa Agropecuária Brasileira, v.34, n.11, p.1975-1982, 1999.

FIGUEIREDO, M.L.C. et al. Effect of Telenomus remus Nixon (Hymenoptera: Scelionidae) density on control of Spodoptera frugiperda (Smith) (Lepidoptera: Noctuidae) egg masses upon release in maize field. Revista Brasileira de Milho e Sorgo, v.1, n.2, p.12-19, 2002.

FINNEY, D.J. Was this in your statistics textbook? V. Transformation of Data. Experimental Agriculture, v.25, p.165-175, 1989.

GERLING, D. The developmental biology of Telenomus remus Nixon (Hym.: Scelionidae). Bulletin of Entomological Research, v.61, p.385-488, 1972.

GONZÁLEZ , C.E.; ZOCCO, J.L. Control integrado de Spodoptera frugiperda (Smith) utilizando Telenomus remus (Nixon) en Zea mays L. Revista de Investigación AgrícolaDANAC, v.1, p.201-219, 1996.
GUPTA, M.; PAWAR, A.D. Multiplication of Telenomus remus Nixon on Spodoptera litura (Fabricius) reared on artificial diet. Journal of Advanced Zoology, v.6, p.13-17, 1985.

HADDAD, M.L. et al. MOBAE, modelos bioestatísticos aplicados à entomologia. Piracicaba, ESALQ/USP, 1995. 44p. (Manual).

HERNÁNDEZ, D.; DÍAZ, F. Efecto de la temperatura sobre el desarrollo de Telenomus remus Nixon (Hymenoptera: Scelionidae) parasitoide de Spodoptera frugiperda (Smith) (Lepidoptera: Noctuidae). Boletin de Entomologia Venezolana, v.11, p.149-153, 1996.

HIGLEY, L.G. et al. Degray: a program for calculation degreedays, and assumptions behind the degre-day approach. Environmental Entomology, v.15, p.999-1016, 1986.

JOSHI, B.G. et al. Some observations on Telenomus remus Nixon, an egg parasitoid of the tobacco caterpillar, Spodoptera litura (F.). Tobacco Research, v.2, p.17-20, 1976.

KASTEN JR., A.A. et al. Dados biológicos comparativos de Spodoptera frugiperda em duas dietas artificiais e substrato natural. Revista de Agricultura, v.53, n.1, p.68-78, 1978.

OLIVEIRA, R.C. et al. Criação de Telenomus remus Nixon (Hymenoptera: Scelionidae) para o controle da lagarta-docartucho, Spodoptera frugiperda Smith (Lepidoptera: Noctuidae). In: DE BORTOCI, S.A. et al. (Eds.). Técnicas de criação de agentes de controle biológico. Jaboticabal: FUNEP, 2006. p.151-166.

PARRA, J.R.P. Técnicas de criação de insetos para programas de controle biológico. Piracicaba, SP: Escola Superior de Agricultura Luiz de Queiroz/Fundação de Estudos Luiz de Queiroz, Universidade de São Paulo, 1996. 137p.

PARRA, J.R.P. Técnicas de criação de Anagasta kuehniella, hospedeiro alternativo para produção de Trichogramma. In: PARRA, J.R.P.; ZUCCHI, R.A. (Eds.). Trichogramma e o controle aplicado. Piracicaba: FEALQ, 1997. p.121-150.

PRATISSOLI, D.; PARRA, J.R.P. Desenvolvimento e exigências térmicas de Trichogramma pretiosum RILEY, criados em duas traças do tomateiro. Pesquisa Agropecuária Brasileira, v.35, p.1281-1288, 2000.

SCHWARTZ, A.; GERLING, D. Adult biology of Telenomus remus (Hymenoptera: Scelionidae) under laboratory conditions. Entomophaga, v.19, p.482-492, 1974.

TORRES, J.B. et al. Exigências térmicas e potencial de desenvolvimento dos parasitóides Telenomus podisi (Ashmed) e Trissolcus brochymenae (Ashmead) em ovos do percevejo predador Podisus nigrispinus (Dallas). Anais da Sociedade Entomológica do Brasil, v.26, n.3, p.445-453, 1997.

VINSON, S.B. Comportamento de seleção hospedeira de parasitóides de ovos, com ênfase na família Trichogrammatidae. In: PARRA, J.R.P.; ZUCCHI, R.A. (Eds.). Trichogramma e o controle aplicado. Piracicaba: FEALQ, 1997. p.67-119.

WELZEN, C.R.L. VAN; WAAGE, J.K. Adaptive responses to local mate competition by parasitoid, Telenomus remus. Behavioral Ecology and Sociobiology, v.21, p.359-363, 1987. 